Vol. 7 (1998): 367-380.

\title{
Effect of type of forage offered and breed on perform- ance of crossbred suckler heifers and their calves
}

\author{
Merja Manninen \\ Agricultural Research Centre of Finland, Animal Production Research, \\ FIN-31600 Jokioinen, Finland, e-mail: merja.manninen@mtt.fi \\ Ilmo Aronen \\ Agricultural Research Centre of Finland, Animal Production Research. \\ Current address: Rehuraisio Ltd., PO Box 101, FIN-21201 Raisio, Finland \\ Marja-Leena Puntila \\ Agricultural Research Centre of Finland, Animal Production Research, FIN-31600 Jokioinen, Finland \\ Reijo Heikkilä \\ Agricultural Research Centre of Finland, Karelia Research Station. \\ Current address: Viikki Experimental Farm, PO Box 27, FIN-00014 University of Helsinki, Finland \\ Seija Jaakkola \\ Agricultural Research Centre of Finland, Animal Production Research, FIN-31600 Jokioinen, Finland
}

Thirty Hereford-Ayrshire (HfAy) and 29 Limousine-Ayrshire (LiAy) spring-calving heifers in calf to a Aberdeen Angus $(\mathrm{Ab})$ bull were used to study the effects of cow breed and winter diet on performance. The diets were either primarily based on hay $\left(\mathrm{H},{ }^{2} / 3\right.$ of dry matter $(\mathrm{DM})$ intake, silage $\left.1 / 3\right)$ or silage ( $\mathrm{S}, 2 / 3$ of DM intake, hay $1 / 3$ ). In addition, animals were offered $1.0 \mathrm{~kg}$ milled barley per head daily for two months prior to calving and $1.5 \mathrm{~kg} /$ day from calving until grazing commenced. Animals also had free access to barley straw.

During the indoor feeding period from 15 December to 1 June HfAy-heifers consumed slightly but not significantly more feed DM, metabolizable energy and AAT (amino acids absorbed from the small intestine) than LiAy-heifers on both diets. At the start of the experiment LiAy- and HfAyheifers were 572 and $596(\mathrm{P}<0.05)$ days of age, respectively. Corresponding ages at calving were 732 and 729 days. The type of forage feeding did not affect the rate of pre partum live weight gain (LWG). The calving difficulties observed were minor. Average milk production of HfAy-cows was higher $(\mathrm{P}<0.01)$ than that of LiAy-cows. Calf LWG from birth to weaning was 1058 and $987 \mathrm{~g} /$ day for HfAyand LiAy-progeny, respectively. Corresponding values for the progeny of cows fed S- and H-diets were 1009 and $1036 \mathrm{~g} /$ day. All HfAy-cows and $87.1 \%$ of LiAy-cows were successfully rebred to Charolais $(\mathrm{Ch})$ sires.

Both S- and H-based diets were suitable for crossbred heifers. Although the energy intake was below Finnish recommendations on both diets, particularly pre partum, live weight of $488 \mathrm{~kg}$ for HfAy- and $476 \mathrm{~kg}$ for LiAy-heifers pre partum proved to be adequate. The incidence of calving difficulties was low.

Key words: beef heifers, calf performance, calving difficulty, feed requirement, milk production

(C) Agricultural and Food Science in Finland

Manuscript received June 1997 


\section{AGRICULTURAL AND FOOD SCIENCE IN FINLAND}

Manninen, M. et al. Effect of forage offered and breed on performance of suckler heifers

\section{Introduction}

Most Finnish beef is derived from dairy herds and approximately only six per cent originates from beef suckler herds. Continuous reduction in dairy cow numbers together with a growing consumer demand for quality beef has increased the need for specialized beef production and therefore, knowledge of feeding suckler heifers and cows.

It is known that feeding beef heifers from puberty to weaning of their first calf is a critical period. Under- or over-heifernutrition may have a major influence on calf birth weight, milk production, calf survival, and above all, resumption of oestrus activity (Field 1991). However, information on crossbred replacement beef heifer management under Finnish conditions, with relatively short grazing and long indoor feeding periods, is inadequate.

The purpose of the present experiment was to study the effect of forage type (grass silage$v s$. hay-based diet) on forage intake, live weight, live weight gain, calving difficulty, milk production and rebreeding of Hereford $\times$ Ayrshire (HfAy) and Limousine $\times$ Ayrshire (LiAy) heifers and calf performance. An additional aim of the experiment was also to examine the suitability of direct-cut grass silage in the prevailing cold indoor feeding conditions. Breed types were chosen based on calf availability from farms and the popularity of HfAy animals as crossbred suckler dams. Furthermore, Limousin was the most popular beef breed used during recent years for beef inseminations on dairy herds. Aberdeen Angus $(\mathrm{Ab})$ was chosen as the maiden heifer sire.

\section{Material and methods}

\section{Animals and experimental design}

The experiment was carried out at Tohmajärvi research station located in eastern Finland $\left(62^{\circ}\right.$ $\left.14^{\prime} \mathrm{N}, 30^{\circ} 21^{\prime} \mathrm{E}\right)$. In December, the minimum temperatures recorded inside and outside the cowhouse were $-19^{\circ} \mathrm{C}$ and $-32^{\circ} \mathrm{C}$, respectively (Figure 1). Thirty-two HfAy-heifers with an initial live weight (LW) on 14 December of $436 \mathrm{~kg}$, and $32 \mathrm{LiAy}$-heifers with an initial LW of $393 \mathrm{~kg}$, both breeds in calf to $\mathrm{Ab}$, were used. The experiment commenced 15 December when HfAy- and LiAy-heifers averaged 596 and 572 days old, respectively. At calving both $\mathrm{HfAy}-$ and $\mathrm{LiAy}$ heifers averaged 24 months of age, after which they are referred to as cows. Animals were allocated to four treatments according to their LW and predicted calving date according to a $2 \times 2$ factorial design. Factors were breed type (HfAy and LiAy) and diet (hay-based, $\mathrm{H}$ and silagebased, S). Animals were group-fed, eight animals per pen, two pens per treatment. The experiment was subdivided in two main parts, the indoor feeding period and the grazing period. During the indoor feeding period animals were housed in a barn with an area of $77 \mathrm{~m}^{2} /$ group. Both straw and peat were used as bedding materials. Animals also had access to an outside exercise area of $108 \mathrm{~m}^{2} /$ group.

\section{Feeding and feed sampling}

Animals were fed once a day in the morning. The amount of feed offered and refused was recorded for each group daily. The quantity of forage offered daily was restricted. Hay and silage were given to heifers fed S- and H-diets according to their initial LW and Finnish recommendations (Ojala 1987) which are based on feeding recommendations for dairy cows and heifers given by Salo et al. (1982). On the H-diet the proportion of total forage dry matter (DM) intake was designed to be $2 / 3$ of hay and $1 / 3$ silage. The reverse applied for the S-diet. Pre partum and post partum feeding regimens involved increasing the amount of silage two months before the estimated calving date and after calving. Barley straw was fed ad libitum to all groups. Milled barley was offered individually to heifers at $1.0 \mathrm{~kg} / \mathrm{d}$, two months pre partum and 1.5 
Vol. 7 (1998): 367-380.

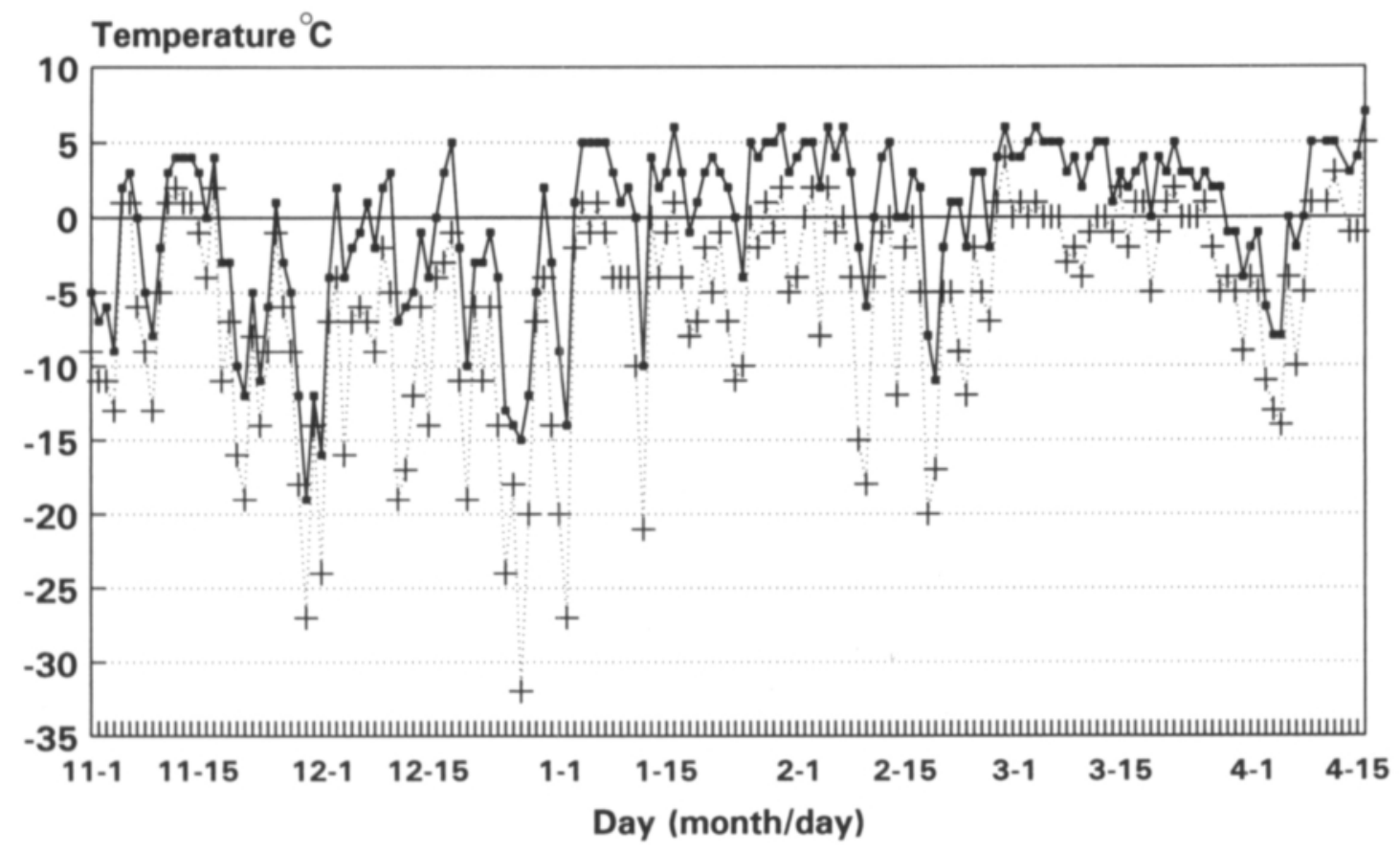

$\rightarrow$ Inside $\quad+\quad$ Outside

Fig. 1. Daily temperature $\left({ }^{\circ} \mathrm{C}\right)$ inside and outside the barn during indoor feeding.

$\mathrm{kg} / \mathrm{d}$ from calving to the start of the grazing season by retaining animals in the feed alley. During the indoor feeding period $150 \mathrm{~g} /$ day of mineral mixture rich in magnesium (Viher-Terki) and $50 \mathrm{~g} /$ week of vitamin mixture (Deb-Karja-Vitan) was given to the heifers. Heifers had free access to water and a salt lick.

Meadow fescue-timothy (Festuca pratensisPhleum pratense) hay was harvested during the first two weeks of July, dried in the swath and baled into small and round bales. Direct-cut grass silage was made using a flail harvester from the same meadow fescue-timothy fields in August and ensiled in three bunker silos using a formic acid based additive (AIV II; $800 \mathrm{~g}$ formic acid/ $\mathrm{kg}, 20 \mathrm{~g}$ orthophosphoric acid/kg), applied at 4$5 \mathrm{l} / \mathrm{t}$ of grass. Field-dried barley straw was baled into small bales. Barley was harvested conventionally and dried in a hot-air drier.
The grazing season commenced on 1 June. Seventeen heifers calving in June were kept inside and started grazing after calving. The continous grazing area allocated for cows was about 30 hectares. Cows had free access to water and a mineral mixture rich in magnesium. As a result of drought in July, August and September cows on pasture were fed during this period of 8 weeks about $2 \mathrm{~kg}$ hay/animal/day. The grazing season ended on 24 August and calves were weaned on either 30 September or 21 October.

During the indoor period feed samples for chemical analyses were taken at every feeding and were pooled over a four week period. Calculated energy values of hay, grass silage, barley straw and barley are based on determined chemical composition and using average digestibility coefficients reported by Tuori et al. (1996). Silage DM content was determined by 


\section{AGRICULTURAL AND FOOD SCIENCE IN FINLAND}

\section{Manninen, M. et al. Effect of forage offered and breed on performance of suckler heifers}

oven drying at $105^{\circ} \mathrm{C}$ for 24 hours and was corrected for volatile losses (volatile fatty acids, ammonia, lactic acid) according to Huida et al. (1986). Fresh silage samples were analysed for $\mathrm{pH}$, water soluble carbohydrates according to Somogyi (1945) with modifications of Salo (1965), lactic acid (Barker and Summerson 1941), volatile fatty acids (Huida 1973), ammonia nitrogen (N) (McCullough 1967) and soluble and total nitrogen $\mathrm{N}$ by the Kjeldahl method. Metabolizable energy (ME) values of feeds were calculated according to MAFF (1975, 1984). Amino acids absorbed in the small intestine (AAT) and protein balance in the rumen (PBV) were calculated according to Tuori et al. (1996).

\section{Live-weight}

Animals were weighed at the beginning of the experiment, 1-7 days pre partum, within 48 hours after parturition and at the beginning and end of the grazing season. All information from five heifers was omitted from the final data because of deaths and abortions. Calves were weighed immediately after birth, at 100 days of age and at weaning. The results of two calves were omitted from the final data because of removal of their dams from the experiment.

\section{Calving difficulties}

All calvings were monitored and assistance was given if calving was prolonged. The character of the calving was recorded using a classification scale: easy calving with no assistance (1), calving with a slight assistance (2) and difficult calving (3).

\section{Milk production}

Milk production of 16 cows, four cows per treatment, was measured using the calf-suckling technique. The cow and her calf were removed from the main group at 1500 hours, and the calf was separated from the dam until 700 hours the following morning. In the morning the calf was weighed and then allowed to suckle after which the calf was reweighed. After suckling the calf was separated from the dam. At 1500 hours this procedure was repeated. The sum of both changes in calf live weight was used as an estimate of dam milk production. Milk yield was measured on days 10, 50, 95 and 145 of lactation. Data of one HfAy-cow fed the H-diet was deleted due to incomplete pre-calving feed intake records.

\section{Rebreeding}

At pasture an oestrus synchronisation procedure was carried out using PRID (Progesterone Releasing Intravaginal Device) on all cows. HfAyand LiAy-cows were subdivided into three groups according to calving date. After the removal of PRID-coils, cows were inseminated using double fixed time artificial insemination (A.I.) with Charolais-semen. A Charolais-bull ran with the cows from 24 July to 29 September.

\section{Statistical analysis}

The GLM procedure of the Statistical Analysis System (SAS 1989) was used for analysis of variance. Animals were in pens, eight animals per pen, two pens per treatment. Pen was used as an experimental unit (Gill 1989). The mean of the pen was used when interpreting feed intake data, while for other traits individual cow data was used.

Data for heifers was analysed according to the following model

$$
y_{i j k l}=\mu+b_{i}+d_{j}+b d_{i j}+p_{k}\left(b d_{i j}\right)+\varepsilon_{i j k l}
$$

where $y_{i j k l}$ is the response variable, $\mu$ is the general mean, $b_{i}$ is the breed, $d_{j}$ is the diet, $b_{i j}$ is their interaction, $p_{k}$ is a random effect due to the pen within treatment and $\varepsilon_{\mathrm{ijkl}}$ is the random error term. In the analysis, the $\mathrm{p}_{\mathrm{k}}\left(\mathrm{bd}_{\mathrm{ij}}\right)$ term with four 
Vol. 7 (1998): 367-380.

Table 1. Duration of feeding periods and age of heifers at calving (days).

\begin{tabular}{|c|c|c|c|c|c|c|c|c|}
\hline \multirow{2}{*}{$\begin{array}{l}\text { Breed } \\
\text { Diet }\end{array}$} & \multicolumn{4}{|c|}{ Hereford $\mathrm{x}$ Ayrshire Limousin $\mathrm{x}$ Ayrshire ${ }^{3}$} & \multirow[b]{2}{*}{ SEM $^{2}$} & \multicolumn{3}{|c|}{ Statistical significance ${ }^{1}$} \\
\hline & Silage & Hay & Silage & Hay & & Breed & Diet & Interaction \\
\hline Number of animals & 15 & 15 & 13 & 16 & & & & \\
\hline $\begin{array}{l}\text { Age at start of } \\
\text { experiment }\end{array}$ & 606 & 586 & 580 & 565 & 7.8 & * & o & NS \\
\hline calving & 134 & 133 & 160 & 160 & 16.4 & NS & NS & NS \\
\hline Age at calving & 740 & 719 & 740 & 725 & 14.7 & NS & NS & NS \\
\hline $\begin{array}{l}\text { From calving to the } \\
\text { start of grazing } \\
\text { (n) }\end{array}$ & $\begin{array}{c}41 \\
(12)\end{array}$ & $\begin{array}{c}35 \\
(14)\end{array}$ & $\begin{array}{l}28 \\
(6)\end{array}$ & $\begin{array}{l}16 \\
(9)\end{array}$ & $11.6^{4}$ & NS & NS & NS \\
\hline
\end{tabular}

${ }^{1} \mathrm{o} \mathrm{P}<0.10 ;{ }^{*} \mathrm{P}<0.05 ;{ }^{* *} \mathrm{P}<0.01 ;{ }^{* * *} \mathrm{P}<0.001$; NS not significant.

${ }^{2} \mathrm{SEM}=$ Standard Error of the Mean.

${ }^{3}$ Means were based on 13 (LiAy-Silage) or 16 (LiAy-Hay) rather than 15 observations. SEM given should be multiplied by 1.08 (LiAy-Silage) or 0.97 (LiAy-Hay) when making comparisions with other mean values.

${ }^{4}$ SEM given should be multiplied by 1.10 (HfAy-Silage), 1.32 (LiAy-Hay) or 1.53 (LiAy-Silage) when making comparisions with the mean value of HfAy-Hay.

${ }^{5}$ Number calved at the start of grazing.

degrees of freedom has been used as an error term.

Data for calves was analysed with the same model with the exception that the effect of sex $\left(\mathrm{s}_{\mathrm{m}}\right)$ and interactions between sex and breed, sex and diet, and sex, breed and diet were included. In this analysis, the $p_{k}\left(\right.$ bds $\left._{i j m}\right)$ term with eight degrees of freedom has been used as an error term. Calf birth date was used as a covariate in the analysis of variance when interpreting calf performance data. Standard error of estimate (SEE) was used to interpret calf data due to variable number of observations per treatment.

\section{Results}

\section{General results}

At the start of the experiment LiAy-heifers were younger $(\mathrm{P}<0.05)$ than HfAy-heifers (Table 1). In addition, heifers on the $\mathrm{H}$-diet tended $(\mathrm{P}<0.10)$ to be younger than those on the S-diet. One LiAyheifer was observed to be open during the indoor feeding period and one HfAy-cow was slaughtered as a result of injury at calving. One LiAy-cow died of septicaemia during the grazing season and another LiAy-heifer aborted. Otherwise the health of heifers was good.

\section{Chemical composition of feeds and feed intake}

Average chemical composition and feed values of experimental feeds are given in Table 2. Silage was of good fermentation quality with a low $\mathrm{pH}$ and low concentration of ammonia $\mathrm{N}$.

Average daily intakes of DM, ME, AAT and PBV during the indoor feeding period are summarised in Table 3. HfAy-heifers consumed numerically more $(\mathrm{P}>0.10) \mathrm{DM}, \mathrm{ME}$ and AAT than $\mathrm{LiAy}$-heifers during the indoor feeding period on both diets. No significant differences were observed in DM and AAT intakes between feeding types but ME intake tended $(\mathrm{P}<0.10)$ to be low- 


\section{AGRICULTURAL AND FOOD SCIENCE IN FINLAND}

Manninen, M. et al. Effect of forage offered and breed on performance of suckler heifers

Table 2. Chemical composition and feed value of experimental feeds.

\begin{tabular}{lcccc}
\hline & Silage & Hay & $\begin{array}{c}\text { Barley } \\
\text { straw }\end{array}$ & Barley \\
\hline Number of samples & 6 & 6 & 6 & 4 \\
Chemical composition (g/kg) & & & & \\
Dry matter (DM) & 191 & 860 & 850 & 869 \\
In DM, & 58 & 57 & 48 & 24 \\
$\quad$ Ash & 131 & 102 & 50 & 122 \\
$\quad$ Crude protein & 55 & 19 & 15 & 23 \\
$\quad$ Ether extract & 314 & 363 & 457 & 54 \\
Crude fibre & 442 & 459 & 430 & 777 \\
$\quad$ Nitrogen free extract & & & & \\
Feed value, & 10.6 & 8.5 & 6.1 & 13.3 \\
$\quad$ ME, MJ/kg DM & 79 & 75 & 57 & 104 \\
AAT, g/kg DM & -3 & -27 & -46 & -48 \\
$\quad$ PBV, g/kg DM & & & & \\
\hline
\end{tabular}

ME, metabolizable energy; ME/11.7 = feed unit, FU.

AAT, amino acids absorbed in the small intestine.

$\mathrm{PBV}$, protein balance in the rumen.

In silage: pH 3.86; in DM (g/kg): lactic acid 53, acetic acid 18, sugar 29.

In total nitrogen $(\mathrm{g} / \mathrm{kg})$ : ammonia $\mathrm{N} 40$, soluble $\mathrm{N} 427$.

er on the hay-based diet than on the silage-based diet. Protein balance in the rumen was also significantly $(\mathrm{P}<0.01)$ lower on the hay-based diet than on the silage-based diet $(-148 \mathrm{~g} \mathrm{PBV} /$ day vs. $-105 \mathrm{~g} \mathrm{PBV/day).} \mathrm{Total} \mathrm{ME} \mathrm{intakes} \mathrm{during}$ the indoor feeding period averaged $72.1 \mathrm{MJ} \mathrm{ME/}$

Table 3. Effect of diet and breed on daily intake of dry matter (DM), energy (metabolizable energy, ME), amino acids absorbed in the small intestine (AAT) and protein balance in the rumen (PBV) during indoor feeding.

\begin{tabular}{|c|c|c|c|c|c|c|c|c|c|}
\hline \multirow{2}{*}{$\begin{array}{l}\text { Breed } \\
\text { Diet } \\
\end{array}$} & & \multicolumn{2}{|c|}{ Hereford $\mathrm{x}$ Ayrshire } & \multicolumn{2}{|c|}{ Limousin $\mathrm{x}$ Ayrshire } & \multirow[b]{2}{*}{ SEM $^{2}$} & \multicolumn{3}{|c|}{ Statistical significance ${ }^{1}$} \\
\hline & & Silage & e Hay & Silage & Hay & & Breed & Diet & eraction \\
\hline \multicolumn{2}{|c|}{ Number of groups } & 2 & 2 & 2 & 2 & & & & \\
\hline \multicolumn{10}{|c|}{ Intake } \\
\hline \multirow{5}{*}{ DM, kg } & Silage & 4.06 & 1.90 & 4.00 & 1.92 & 0.016 & NS & $* * *$ & o \\
\hline & Hay & 2.56 & 4.48 & 2.49 & 4.41 & 0.060 & NS & $* * *$ & NS \\
\hline & Barley straw & 0.03 & 0.05 & 0.01 & 0.03 & 0.010 & o & NS & NS \\
\hline & Barley & 0.71 & 0.70 & 0.49 & 0.52 & 0.133 & NS & NS & NS \\
\hline & Total & 7.51 & 7.27 & 7.13 & 7.03 & 0.179 & NS & NS & NS \\
\hline ME, MJ & Total & 74.3 & 67.7 & 69.9 & 64.8 & 2.12 & NS & o & NS \\
\hline AAT, g & Total & 588 & 561 & 552 & 538 & 17.4 & NS & NS & NS \\
\hline PBV, g & Total & -111 & -152 & -99 & -144 & 6.2 & NS & $* *$ & NS \\
\hline
\end{tabular}

${ }^{1}$ o $\mathrm{P}<0.10$; * $\mathrm{P}<0.05$; ** $\mathrm{P}<0.01$; *** $\mathrm{P}<0.001$; NS not significant.

${ }^{2} \mathrm{SEM}=$ Standard Error of the Mean.

* Including mineral mixture, $150 \mathrm{~g} /$ day. 
Vol. 7 (1998): 367-380.

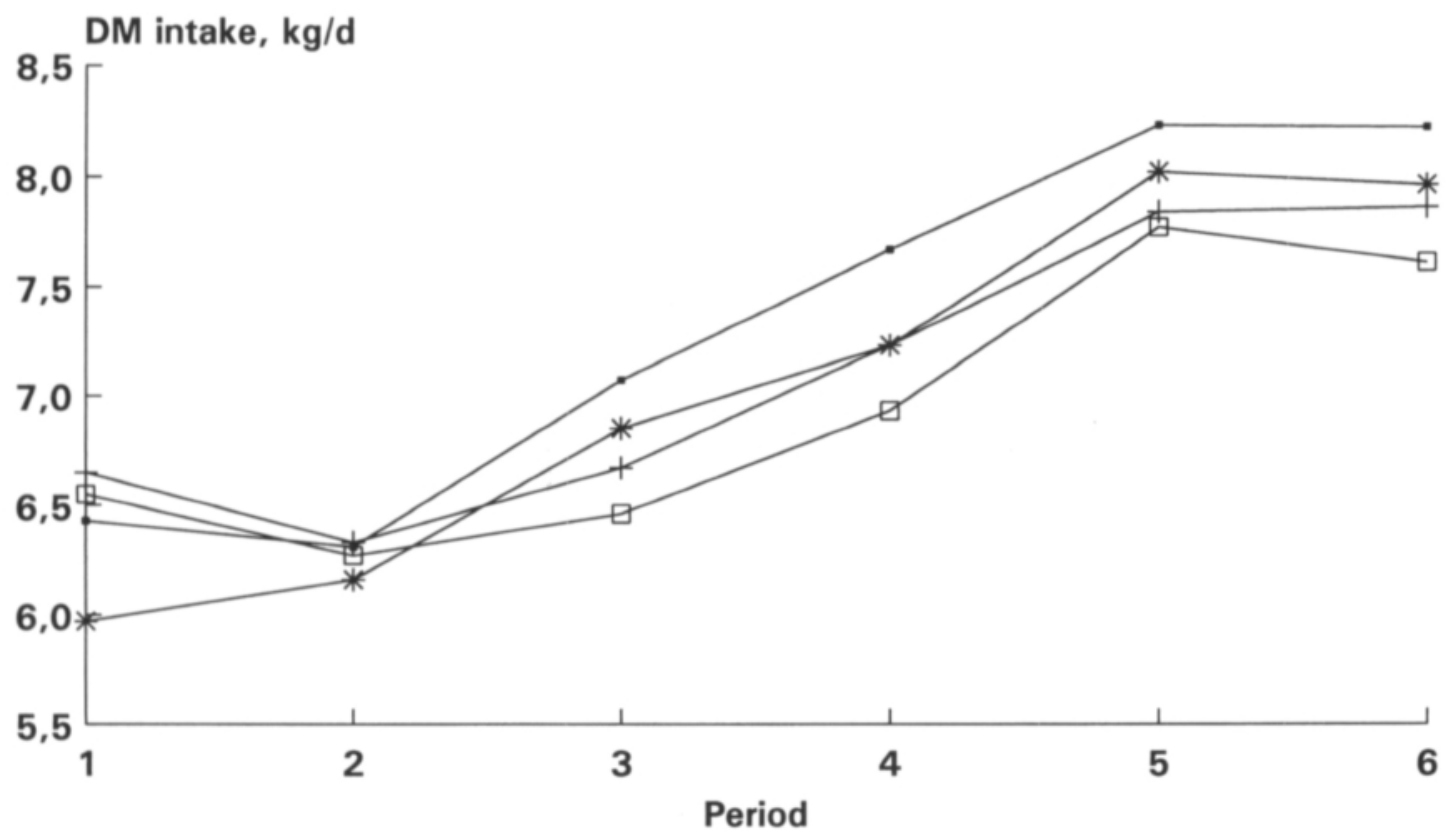

$\because$ HfAy-S $\quad$ HfAy-H $\quad$ - LiAy-S $\quad \square-$ LiAy-H

Fig. 2. Average daily intake of dry matter (DM) from experimental feeds on hay (H)- and silage (S)-based diets during indoor feeding.

day and 66.2 MJ ME/day on the silage and hay based diets, respectively. During the indoor period total ME intakes averaged 71.0 MJ ME/day and 67.4 MJ ME/day for HfAy- and LiAy-animals, respectively. Energy intake from barley was higher for HfAy- than LiAy-heifers due to earlier calving of the former and thus, a longer post partum period before the start of the grazing season. DM intake of experimental treatments during indoor feeding are shown in Figure 2 .

\section{Live weight of heifers}

The initial LW of LiAy-heifers was lower $(\mathrm{P}<0.01)$ than that of HfAy-heifers (Table 4). Despite a higher $(\mathrm{P}<0.01)$ live weight gain (LWG) pre partum LW of LiAy-heifers tended $(\mathrm{P}<0.10)$ to be lower than that of HfAy-heifers.
Also pre partum $\mathrm{LW}$ of heifers on the S-diet tended $(\mathrm{P}<0.10)$ to be higher than that of heifers on the $\mathrm{H}$-diet. No interactions between breed and feeding on pre partum LW were observed. At the end of the experimental grazing season LiAycows were still significantly $(\mathrm{P}<0.05)$ lighter than HfAy-cows. Heifers overwintered on the $\mathrm{S}$-diet continued to be numerically heavier at the end of the grazing season than those overwintered on the H-diet.

\section{Age of heifers at calving and calving difficulties}

Mean age at calving of both HfAy- and LiAyheifers was 24 months. As a consequence of the younger age of LiAy-heifers at the start of the experiment, the period from the start to calving 


\section{AGRICULTURAL AND FOOD SCIENCE IN FINLAND}

Manninen, M. et al. Effect of forage offered and breed on performance of suckler heifers

Table 4. Live weight (LW) and live weight gain (LWG) during indoor feeding and grazing.

\begin{tabular}{|c|c|c|c|c|c|c|c|c|}
\hline \multirow{2}{*}{$\begin{array}{l}\text { Breed } \\
\text { Diet }\end{array}$} & \multicolumn{5}{|c|}{ Hereford $x$ Ayrshire Limousin x Ayrshire" } & \multicolumn{3}{|c|}{ Statistical significance ${ }^{1}$} \\
\hline & Silage & Hay & Silage & Hay & SEM $^{2}$ & Breed & Diet & teraction \\
\hline Number of animals & 15 & 15 & 13 & 16 & & & & \\
\hline \multicolumn{9}{|l|}{ LW, kg } \\
\hline Initial, 15 December & 449 & 423 & 390 & 396 & 7.1 & ** & NS & o \\
\hline Pre partum & 498 & 478 & 478 & 473 & 4.6 & o & o & NS \\
\hline Post partum & 458 & 445 & 443 & 419 & 8.1 & o & o & NS \\
\hline $\begin{array}{l}\text { At the beginning of } \\
\text { grazing, } 1 \text { June }\end{array}$ & 438 & 420 & 434 & 408 & 8.8 & NS & o & NS \\
\hline $\begin{array}{l}\text { At the end of experim } \\
\text { grazing, } 24 \text { August }\end{array}$ & $\begin{array}{r}\text { nental } \\
\quad 449\end{array}$ & 426 & 419 & 420 & 4.6 & * & o & o \\
\hline \multicolumn{9}{|l|}{ LWG, g/day } \\
\hline $\begin{array}{l}\text { From start to calving } \\
\text { From calving to start }\end{array}$ & of 357 & 407 & 554 & 480 & 25.8 & ** & NS & o \\
\hline grazing & -584 & -763 & -434 & -390 & 321.6 & NS & NS & NS \\
\hline During grazing & 160 & 74 & -220 & 165 & 71.3 & NS & NS & $*$ \\
\hline
\end{tabular}

'o $\mathrm{P}<0.10 ;{ }^{*} \mathrm{P}<0.05 ;{ }^{* *} \mathrm{P}<0.01 ;{ }^{* * *} \mathrm{P}<0.001$; NS not significant.

${ }^{2} \mathrm{SEM}=$ Standard Error of the Mean.

" Means based on 13 (LiAy-Silage) or 16 (LiAy-Hay) rather than 15 observations. SEM given should be multiplied by 1.08 (LiAy-Silage) or 0.97 (LiAy-Hay) when making comparisions with other mean values.

was longer $(\mathrm{P}>0.10)$ for LiAy-heifers than for HfAy-heifers (Table 1). The calving period was 104 days. Eight calves (13\%) were born in March, 15 (24\%) in April, 22 (35\%) in May and $18(28 \%)$ in June. Two of the calves were dead at parturition, one died immediately after birth and one died accidentally.

A significant interaction $(\mathrm{P}<0.01)$ between breed and sex was observed for calving difficulty (Table 5). HfAy-heifers had more calving difficulties with male than female calves (1.50 vs. 1.06) while no differences were observed between sexes born to LiAy (1.34 vs.1.32). Also a significant $(\mathrm{P}<0.001)$ interaction between diet and calf sex on calving difficulty was observed. Heifers on the S-diet had more calving difficulties when they had male than female calves ( 1.78 vs. 1.21) while heifers on the $\mathrm{H}$-diet producing female calves had slightly more calving difficulties than those producing male calves $(1.18$ vs.1.06).

\section{Live weight of calves}

There was no effect of breed on calf birth weight but diet and sex of calves tended $(\mathrm{P}<0.10)$ to have an effect on calf birth weight (Table 5). At 100 days of age, male calves were heavier $(\mathrm{P}<0.01)$ than females $(150 \mathrm{~kg}$ vs. $137 \mathrm{~kg})$. At weaning $\mathrm{Ab} \times$ HfAy calves were numerically heavier (197 $\mathrm{kg}$ vs. $188 \mathrm{~kg})$ but older $(\mathrm{P}<0.05)$ than $\mathrm{Ab} x \mathrm{LiAy}$ calves ( 163 days vs. 141 days). The rate of LWG from birth to weaning of $\mathrm{Ab} x$ HfAy calves was numerically higher than that of $\mathrm{Ab} \times \mathrm{LiAy}$ calves (1058 g/day vs. $987 \mathrm{~g} /$ day). The rate of LWG from birth to weaning of male calves was higher $(\mathrm{P}<0.05)$ than that of female calves $(1078 \mathrm{~g} /$ day $v s .968 \mathrm{~g} /$ day). The average weaning weight, (i.e. 151-day weight), was higher $(\mathrm{P}<0.05)$ for male than female calves (198 kg vs. $179 \mathrm{~kg})$. No interactions between breed, type of feeding and sex on calf weight, age or rate of LWG were observed. 
Vol. 7 (1998): 367-380.

Table 5. Effect of type of feeding, breed and sex on calving difficulty and calf performance.

\begin{tabular}{|c|c|c|c|c|c|c|c|c|c|c|c|c|}
\hline \multirow{3}{*}{$\begin{array}{l}\text { Breed } \\
\text { Diet } \\
\text { Sex }\end{array}$} & \multicolumn{4}{|c|}{ Aberdeen Angus x HfAy } & \multicolumn{4}{|c|}{ Aberdeen Angus x LiAy } & \multirow{2}{*}{\multicolumn{4}{|c|}{ Statistical significance' }} \\
\hline & \multicolumn{2}{|c|}{ Silage } & \multicolumn{2}{|c|}{ Hay } & \multicolumn{2}{|c|}{ Silage } & \multicolumn{2}{|c|}{ Hay } & & & & \\
\hline & Male & Female & Male & Female & Male & Female & Male & Female & $\mathrm{SEE}^{2}$ & Breed & Diet & Sex \\
\hline Number of animals & $12^{*}$ & 4 & 8 & 7 & $9^{*}$ & 5 & 7 & $9^{*}$ & & & & \\
\hline Calving difficulty ${ }^{3,4}$ & 2.00 & 1.00 & 1.00 & 1.13 & 1.55 & 1.42 & 1.13 & 1.23 & 0.186 & NS & $* * *$ & ** \\
\hline \multicolumn{13}{|l|}{ Live weight, kg } \\
\hline At birth & 40.8 & 37.7 & 36.4 & 34.3 & 36.8 & 36.5 & 38.1 & 34.6 & 3.98 & NS & o & o \\
\hline 100-day & 153 & 143 & 151 & 138 & 143 & 136 & 152 & 132 & 12.9 & NS & NS & ** \\
\hline At weaning & 205 & 194 & 198 & 192 & 188 & 181 & 199 & 184 & 22.3 & NS & NS & NS \\
\hline 151 -day ${ }^{5}$ & 201 & 189 & 202 & 185 & 189 & 167 & 199 & 175 & 26.4 & NS & NS & $*$ \\
\hline Weaning age (days) & 156 & 173 & 154 & 169 & 140 & 138 & 138 & 147 & 30.9 & * & NS & NS \\
\hline $\begin{array}{l}\text { Live weight gain } \\
\text { from birth to } \\
\text { weaning (g/day) }\end{array}$ & 1093 & 1021 & 1110 & 1010 & 1025 & 899 & 1083 & 944 & 152.0 & NS & NS & * \\
\hline
\end{tabular}

'o $\mathrm{P}<0.10 ;{ }^{*} \mathrm{P}<0.05 ;{ }^{* *} \mathrm{P}<0.01 ;{ }^{* * *} \mathrm{P}<0.001$; NS not significant.

${ }^{2} \mathrm{SEE}=$ Standard Error of the Estimate.

${ }^{3}$ 1; Easy, no assistance, 2; Slight assistance, 3; Difficult calving.

${ }^{4} \mathrm{~A}$ significant interaction between breed and $\operatorname{sex}(\mathrm{p}<0.01)$, diet and $\operatorname{sex}(\mathrm{p}<0.001)$ and breed, diet and $\operatorname{sex}(\mathrm{p}<0.01)$.

${ }^{5}$ 151-day weight; average calf weaning age.

' $\mathrm{n}=12$ for calving difficulty and birth weight then $\mathrm{n}=11$

$\mathrm{n}=9$ for calving difficulty and birth weight then $\mathrm{n}=8$.

\section{Milk production}

There was no effect of diet on milk production (Table 6). Daily milk production of HfAy-cows was marginally higher at day 10 and day 95 of lactation and much higher $(\mathrm{P}<0.05)$ at day 50 and day 145 of lactation than that of LiAy-cows. Overall milk production of HfAy-cows was higher $(\mathrm{P}<0.01)$ than that of LiAy-cows $(7.7 \mathrm{~kg} /$ day vs. $5.8 \mathrm{~kg} /$ day).

\section{Conception rate}

All HfAy-cows starting the grazing period were successfully bred while only $87.1 \%$ of LiAycows were recorded to be in calf during pregnancy testing conducted in the autumn. Type of feeding during the indoor period did not affect conception rate since $93.3 \%$ of cows on the Sdiet and $93.5 \%$ of cows on the H-diet were pregnant. Overall, $50.8 \%$ of cows were in calf to A.I.,

Table 6. Effect of type of feeding and breed on milk production (kg/day) of crossbred suckler cows.

\begin{tabular}{|c|c|c|c|c|c|c|c|c|}
\hline \multirow{2}{*}{$\begin{array}{l}\text { Breed } \\
\text { Diet }\end{array}$} & \multicolumn{2}{|c|}{ Hereford $\mathrm{x}$ Ayrshire } & \multicolumn{2}{|c|}{ Limousin $\mathrm{x}$ Ayrshire } & \multirow[b]{2}{*}{ SEM $^{2}$} & \multicolumn{3}{|c|}{ Statistical significance ${ }^{1}$} \\
\hline & Silage & Hay $^{\circ}$ & Silage & Hay & & Breed & Diet & eraction \\
\hline Number of animals & 4 & 3 & 4 & 4 & & & & \\
\hline \multicolumn{9}{|l|}{ Day of lactation } \\
\hline 10 & 7.0 & 7.4 & 5.5 & 6.0 & 0.58 & o & NS & NS \\
\hline 50 & 8.8 & 7.6 & 5.8 & 6.5 & 0.59 & $*$ & NS & NS \\
\hline 95 & 9.8 & 9.2 & 7.3 & 6.4 & 1.13 & o & NS & NS \\
\hline 145 & 6.6 & 5.5 & 5.0 & 3.7 & 0.56 & $*$ & NS & NS \\
\hline Mean & 8.1 & 7.4 & 5.9 & 5.6 & 0.28 & $* *$ & NS & NS \\
\hline
\end{tabular}

'o $\mathrm{P}<0.10$; * $\mathrm{P}<0.05 ;{ }^{* *} \mathrm{P}<0.01 ;{ }^{* * *} \mathrm{P}<0.001$; NS not significant.

${ }^{2} \mathrm{SEM}=$ Standard Error of the Mean, for ${ }^{\circ}$ multiply by 1.22 . 
Manninen, M. et al. Effect of forage offered and breed on performance of suckler heifers

$42.6 \%$ to natural service and $6.6 \%$ failed to become pregnant.

\section{Discussion}

\section{Feed intake}

Feed values of hay and silage were satisfactory. In a cold environment the intake of unwilted grass silage may be depressed due to freezing. In the present study feed intakes were good and there were no refusals of silage, hay or barley. Barley straw was available ad libitum, but intake was minimal. On the coldest days of winter, freezing of unwilted grass silage caused some minor problems when weighing and apportioning feed for treatment groups.

On the S-diet both breeds received more energy (ME MJ) than heifers on the $\mathrm{H}$-diet during the experiment except from the start of the experiment to the beginning of pre partum feeding. At the onset of the experiment, DM intake was $1.50 \mathrm{~kg} / 100 \mathrm{~kg}$ live weight for HfAy-heifers and $1.59 \mathrm{~kg} / 100 \mathrm{~kg}$ live weight for LiAy-heifers.

In Finland there are no official feeding standards for replacement beef heifers, but recommendations based on feeding standards of dairy heifers and cows are available (Salo et al. 1982, Tuori et al. 1996). The calculated AAT intake before calving exceeded recommendations, but DM and energy intake were below Finnish recommendations, particularly for the $\mathrm{H}$-diet just before and after calving. Although indoor energy intake in this experiment was below recommendations (5$15 \%)$ particularly post partum, it appeared to be sufficient since conception rates were good. DM intakes were also considerably lower than minimum limits recommended by Macartney and Moon (1974) and Field (1991). However, feeding levels on the S-diet were in good agreement with the recommendations reported by Drennan (1988).
Nutrition, especially energy intake, is the most critical factor influencing the interval from calving to first oestrus. Dunn et al. (1969) observed that the level of energy intake can markedly change reproductive performance in twoyear-old heifers as the pregnancy rate 120 days after calving was directly related to post-calving energy intake. Nicol (1977) also reported that a low level of nutrition for 40 days post calving for two- and three-year-old Aberdeen Angus and Aberdeen Angus crosses resulted in a delay of seven days to first oestrus compared to animals on a higher feeding level. Intervals from calving to first oestrus were not recorded due to the synchronisation programme during the mating period and thus, the effect of diet, energy level and breed on the interval to first oestrus can not be clearly identified. However, conception rate was good for all cows.

\section{Live weight of cows}

The higher LWG of LiAy-heifers may result from their younger age, larger size and later maturity which is typical for larger beef breeds such as the Limousin and Charolais. LWG of heifers pre partum was $382 \mathrm{~g} /$ day for HfAy-heifers and 517 g/day for LiAy-heifers and was thus, satisfactory when compared with recommendations given by Byers et al. (1987). The results observed in this experiment have to be compared with those observed with other Hereford- or Limousincrosses because comparable to that used crosses in this experiment are not common elsewhere. The LW of heifers before calving was also satisfactory if compared to the results reported by Drennan (1987) with crossbred heifers although in contrast to the present study Limousin $\times$ Friesian-heifers were heavier than Hereford $x$ Friesians before calving. In another experiment More O'Ferrall and Drennan (1989) reported that Hereford $\times$ Friesian first-calf heifers reached an average of $393 \mathrm{~kg}$ and Simmental $\times$ Friesian firstcalf heifers reached an average of $422 \mathrm{~kg}$ at 32 months of age in autumn. However, in the present experiment HfAy- and LiAy-heifers reached 80 
Vol. 7 (1998): 367-380.

to $85 \%$ of expected mature LW at calving as recommended by Rittenhouse and Roath (1989).

Both the hay- and silage-based feeding systems were suitable for Hereford- and Limousin crosses in the current circumstances. During the grazing season LWG was quite poor for HfAycows previously on the $\mathrm{H}$-diet in winter and for LiAy-cows offered the S-diet. The latter, in fact, lost LW. Negative LWG may reflect insufficient energy intake from grass due to drought during the grazing season. Additional feeding of hay appeared to be inadequate. On the other hand, the good conception rate of all cows reflects sufficient energy intake and condition from calving to the start of insemination and mating.

\section{Calving difficulties}

Generally, few severe calving difficulties were observed in this experiment although $29.5 \%$ of all calvings were assisted. Ease of calving probably reflects the sire genotype as was suggested by Roux et al. (1987), who used either Aberdeen Angus or Aubrac sires on Friesian or Charolais $\times$ Friesian heifers and by Harte (1987), who used Hereford $\times$ Friesian heifers and Aberdeen Angus bulls. Puntila et al. (1985) reported that HfAy-heifers had marginally greater calving difficulties than LiAy-heifers calving to a Limousin sire. Male calves in the present experiment were heavier at birth than female calves (38.0 $\mathrm{kg} v$ s. $35.9 \mathrm{~kg}$ ). It can be assumed that $\mathrm{LW}$ at calving was optimum for both HfAy- and LiAyheifers to avoid dystocia which is in agreement with the findings by Bellows et al. (1971). Sinclair and Lowman (1990) observed that feeding level pre partum affected the birth weight of calves as Hereford-Friesian heifers in calf to a Simmental bull given only $50 \mathrm{MJ} \mathrm{ME} /$ day in the last 12 weeks of pregnancy gave birth to calves which were significantly $(\mathrm{p}<0.05)$ lighter than those from heifers receiving 75 MJ ME/day. Keane et al. (1991) did not observe any effect of different feeding levels pre partum (41 days before calving cows were fed straw ad libitum plus $0.5 \mathrm{~kg}$ or $2.0 \mathrm{~kg}$ concentrates per head daily) on calf birth weight or calving difficulties of crossbred beef heifers.

\section{Live weight of calves}

The amount of milk is the most important factor affecting calf growth rate during the first three or four months, particularly for spring-born calves (Allen and Kilkenny 1984). In the present experiment the calf performance was affected only by sex. Although there was no difference in the calving age of heifers, LiAy-heifers calved significantly later in spring than HfAy-heifers. Lesmeister et al. (1973) observed that earlier born calves grew significantly faster from birth to weaning than calves born in later groups. Calves from LiAy-heifers were younger at the start of the grazing season which probably also affected their LWG. Pre-weaning gains (male calves $1078 \mathrm{~g} /$ day $v s$. female calves $968 \mathrm{~g} /$ day) measured in this experiment were, however, satisfactory when compared to pre-weaning gains of calves from Hereford x Friesian, Simmental $x$ Friesian and Limousin $x$ Friesian two-year-old dams reported by More O'Ferrall and Drennan (1989).

\section{Milk production}

The first lactation is probably the most important period in the life of a beef cow. Nutrient requirements of a heifer is greatest during this period because she has to maintain her body, nurse a calf, recover from calving, come into heat, rebreed, and continue to grow (Macartney and Moon 1974).

In the present experiment the type of feeding during the indoor period did not affect milk production, but there was a significant breed affect. It may be possible that the lower milk production which was measured for LiAy-heifers resulted from their later average birth date and, the later maturing of Limousin-crosses. However, milk production for both types of cows was satisfactory as judged from LWG of their calves. 
Manninen, $M$. et al. Effect of forage offered and breed on performance of suckler heifers

The effect of breed on milk production is in agreement with the results observed by Jenkins and Ferrell (1992) and Jeffery et al. (1971). In contrast to the observations of Puntila et al. (1985) HfAy-heifers produced more milk than LiAy-heifers. However, milk production of HfAy-heifers was in good agreement with those reported by Chigaru and Topps (1981) with Hereford $x$ British Friesian heifers. In the present experiment the peak milk yield was observed 95 days after parturition. Somerville and Lowman (1980) observed a peak milk yield of $7.7 \mathrm{~kg}, 31$ days post partum using the calf-suckling technique with Hereford $\times$ British Friesian heifers and $7.6 \mathrm{~kg}, 26$ days post partum using the machine-milking technique with the same heifer type.

Milk production observed in this experiment with crossbred beef cows seems to be quite satisfactory when compared to milk production figures achieved with purebred Hereford-heifers (Johnsson and Obst 1984, Fleck et al. 1980) and other purebred adult beef cows reported by Andersen (1990). The main reason for good milk production was undoubtedly the effect of the Ayrshire breed although it can be assumed that Ayrshire dairy cows inseminated with beef semen would have a low production potential and are most likely to be the lowest producing animals in a dairy herd.

\section{Conception rate}

It can be assumed, in spite of the negative LWG from calving to the start of the grazing season, that cows were at least in moderate condition at the start of the grazing season. The lower conception rate of LiAy heifers may reflect their slightly younger age and later maturity. Deutscher and Whiteman (1971) reported that under range conditions only $13 \%$ of Angus-Holstein crossbreds nursing heifers rebred compared to
$63 \%$ of purebreds nursing Angus-heifers. This would indicate that nutritional requirements of better milking crossbreds are higher in order to ensure good reproductive performance. Van Niekerk et al. (1990) observed that winter and summer levels of nutrition only slightly affected conception rate of Simmental heifers.

\section{Conclusions}

Both H- and S-based diets used in this experiment seemed to be suitable for crossbred beef heifers during indoor feeding in a cold environment. Calculated ME and AAT intakes were lower on the H-diet than the S-diet but this did not cause any major performance differences. DM intake was below minimum recommendations on both diets. On the coldest days of the indoor feeding period, freezing of fresh grass silage caused minor technical problems. This may be avoided by using wilted grass silage, hay-based diets or increasing the amount of forages of lower nutritive value but higher DM content.

Calving difficulties observed in this experiment were minor which reflects the size of heifers being adequate at calving and suitable feeding level pre partum. In addition, use of an easy calving breed sire probably contributed to the low incidence of calving difficulties. Milk production of both crossbred heifer types was satisfactory as indicated by the growth rate of their calves. Although LWG of heifers before the grazing season and during the summer was not good it appeared to be sufficient to achieve a high conception rate. The reason for reduced conception rates in LiAy cows may due to a later calving date than HfAy cows.

Acknowledgements. The authors are grateful to Mr Helge Laamanen and his staff for their technical assistance during the experiment. Thanks are also due to Lic. Vet. Med. Juha Hurmalainen for his excellent cooperation with oestrus synchronisation program. 
Vol. 7 (1998): 367-380.

\section{References}

Allen, D. \& Kilkenny, B. 1984. Planned beef production. 2nd Ed. Granada Publishing. London. 229 p.

Andersen, H. Refsgaard. 1990. Ammekoens energiebehov og foderoptagelseskapasitet. Landbrugsministeriet, Beretning fra Statens Husdyrbrugsforsøg, 669. $64 \mathrm{p}$.

Barker, S.B. \& Summerson, W.H. 1941. The colorimetric determination of lactic acid in biological material. Journal of Biological Chemistry 138: 535-554.

Bellows, R.A., Gibson, R.B., Anderson, D.C. \& Short, R.E. 1971. Precalving body size and pelvic area relationships in Hereford heifers. Journal of Animal Science 33: 455-457.

Byers, F.M., Schelling, G.T. \& Greene, L.W. 1987. Managing the growing heifer. Beef, June, 34-37.

Chigaru, P.R.N. \& Topps, J.H. 1981. The composition of body-weight changes in underfed lactating beef cows. Animal Production 32: 95-103.

Deutscher, G.H. \& Whiteman, J.V. 1971. Productivity as two-year-olds of Angus-Holstein crossbreds compared to Angus heifers under range conditions. Journal of Animal Science 33: 337-342.

Drennan, M.J. 1987. A comparison of Hereford $\times$ Friesian and Limousin $\times$ Friesian as suckler dams. Proceedings of the 92nd meeting of the British Society of Animal Production. Animal Production 44: 492.

- 1988. Management of the suckler cow herd in winter. Farm and Food Research 19, 6: 24-25.

Dunn, T.G., Ingalls, J.E., Zimmerman, D.R. \& Wiltbank, J.N. 1969. Reproductive performance of 2-year-old Hereford and Angus heifers as influenced by pre- and post-calving energy intake. Journal of Animal Science 29: 719-726.

Field, J. 1991. Feeding and managing replacement beef heifers. Factsheet. October. Ministry of Agriculture and Food. Ontario. 4 p.

Fleck, A.T., Schalles, R.R. \& Kiracofe, G.H. 1980. Effect of growth rate through 30 months on reproductive performance of beef heifers. Journal of Animal Science 51: 816-821.

Gill, J.L. 1989. Statistical aspects of design and analysis of experiments with animals in pens. Journal of Animal Breeding and Genetics 106: 321-334.

Harte, F.J. 1987. Once-bred heifers, efficient system for extra calves. Farm and Food Research 18, 6: 2930.

Huida, L. 1973. Quantitative determination of volatile fatty acids from rumen sample and silage by gas-liquid chromatography. Journal of the Scientific Society of Agricultural Science in Finland 45: 438-488.

- , Văătăinen, H. \& Lampila, M. 1986. Comparision of dry matter contents in grass silages as determined by oven drying and gas chromatographic water analysis. Annales Agriculturae Fenniae 25: 215-230.

Jeffery, H.B., Berg, R.T. \& Hardin, R.T. 1971. Factors influencing milk yield of beef cattle. Canadien Journal of Animal Science 51: 551-560.

Jenkins, T.G. \& Ferrell, C.L. 1992. Lactation characteristics of nine breeds of cattle fed various quantities of dietary energy. Journal of Animal Science 70: 16521660.

Johnsson, I.D. \& Obst, J.M. 1984. The effects of level of nutrition before and after 8 months of age on subsequent milk and calf production on beef heifers over three lactations. Animal Production 38: 57-68.

Keane, M.G., Harte, F.J. \& Drennan, M.J. 1991. Productivity of once-calved heifers - Effects of pre-calving feeding level and heifer breed type. Irish Journal of Agricultural Research 30: 85-98.

Lesmeister, J.L., Burfening, P.J. \& Blackwell, R.L. 1973. Date of first calving in beef cows and subsequent calf production. Journal of Animal Science 36: 1-6.

Macartney, R.E. \& Moon, R.R. 1974. Feeding and managing replacement heifers. Factsheet. January. Ministry of Agriculture and Food. Ontario. 3 p.

MAFF 1975. Energy allowances and feeding systems for ruminants. Tech. Bull. 33. Her Majesty's Stationery Office, London. 79 p.

MAFF 1984. Energy allowances and feeding systems for ruminants. Reference Book 433. Her Majesty's Stationery Office, London. 85 p.

McCullough, M.E. 1967. The determination of ammonia in whole blood by direct colorimetric method. Clinical Chimica Acta 17: 297-304.

More O'Ferrall, G.J. \& Drennan, M.J. 1989. Breed crosses as suckler dams. Farm and Food Research 20, 5 : 18-20.

Nicol, A.M. 1977. The influence of plane of nutrition immediately post-calving on the performance of beef cows. The Proceedings of the New Zealand Society of Animal Production 37: 103-108.

Niekerk, A. van, Kernick, R. \& Lishman, A.W. 1990. The effect of winter and summer nutritional levels on the reproductive performance of beef heifers bred at 2 years of age. Animal Production 51: 255-262.

Ojala, M. 1987. Lihakarjan kasvatus. 1st Ed. Otava. p. $47-75$.

Puntila, M.-L., Poutiainen, E., Myllylä, M. \& Heikkilä, T. 1985. Itseuudistuva naudanlihantuotanto kotoisin rehuin. Kotieläintieteen laitos, Helsingin Yliopisto. Helsinki. 53 p.

Rittenhouse, L. \& Roath, R. 1989. It's a balancing act. Beef, Spring: 16-21.

Roux, M., Teissier, J.H., Bonnemaire, J. \& Dumount, R. 1987. Early calving heifers versus maiden heifers for beef production from dairy herds. I. The effects of genotype (Friesian and Charolais $\mathrm{x}$ Friesian) and two feeding levels in the rearing period on growth and carcass quality. Livestock Production Science 16: 119.

Salo, M.-L. 1965. Determination of carbohydrate fractions in animal foods and faeces. Acta Agralia Fennica 105: 1-102.

Salo, M.-L., Tuori, M. \& Kiiskinen, T. 1982. Rehutaulukot ja ruokintanormit. Helsinki. $70 \mathrm{p}$.

SAS 1989. SAS/STAT. User's Guide. SAS Institute Inc., Cary, N.C., U.S.A.

Sinclair, K.D. \& Lowman, B.G. 1990. The effects of dif- 
Manninen, M. et al. Effect of forage offered and breed on performance of suckler heifers

fering patterns of energy intake in mid and late pregnancy in maiden heifers. Animal Production 50: 581.

Somerville, S.H. \& Lowman, B.G. 1980. A comparision of machine-milking and the calf-suckling technique as methods of measuring the milk yield of beef cows. Animal Production 30: 365-372.
Somogyi, M. 1945. A new reagent for the determination of sugars. Journal of Biological Chemistry 160: 6168.

Tuori, M., Kaustell, K., Valaja, J., Aimonen, E., Saarisalo, E. \& Huhtanen, P. 1996. Rehutaulukot ja ruokintasuositukset. Helsinki. $99 \mathrm{p}$.

\title{
SELOSTUS
}

\section{Karkearehuruokinnan vaikutus risteytyshiehojen ja niiden vasikoiden kehitykseen sisäruokinta- ja laidunkaudella}

\author{
Merja Manninen, Ilmo Aronen, Marja-Leena Puntila, Reijo Heikkilä ja Seija Jaakkola \\ Maatalouden tutkimuskeskus ja Helsingin yliopisto
}

Tutkimuksessa selvitettiin heinävaltaisen (noin $2 / 3$ kuiva-aineen syönnistä heinää) ja säilörehuvaltaisen (noin $2 / 3$ kuiva-aineen syönnistä säilörehua) ruokinnan vaikutuksia Hereford- Ayrshire- (HfAy) ja Limousine-Ayrshire- (LiAy) risteytyshiehojen elopainon kehitykseen, poikimiseen, maidontuotantoon ja tiinehtymiseen. Lisäksi selvitettiin risteytyshiehojen Aberdeen Angus- (Ab) sonneista syntyneiden vasikoiden kehitystä syntymästä vieroitukseen.

Säilörehuruokinnalla olleet HfAy-hiehot saivat sisäruokintakaudella keskimäärin 74,3 MJ ME/pv ja LiAy-hiehot 69,9 MJ ME/pv ja heinävaltaisella ruokinnalla olleet vastaavasti $67,7 \mathrm{MJ} \mathrm{ME} / \mathrm{pv}$ ja $64,8 \mathrm{MJ}$ $\mathrm{ME} / \mathrm{pv}$. HfAy-hiehojen suurempaan kuiva-aineen syöntiin ja siten suurempaan energian saantin lienee osittain vaikuttanut niiden LiAy-hiehoja hieman suurempi koko, aikaisempi täysikokoisuuden saavuttaminen ja siten ruuansulatuskanavan suurempi tilavuus.

Poikiessa HfAy- ja LiAy-hiehot olivat keskimäärin 24 kuukauden ikäisiä. Poikimiset onnistuivat hyvin, muutamia vaikeita poikimisia esiintyi ja $29,5 \%$ :ssa poikimisista tarvittiin hieman avustusta.

Kokeen alkaessa LiAy-hiehot olivat HfAy-hiehoja kevyempiä. LiAy-hiehojen elopaino lisääntyi poikimiseen mennessä enemmän kuin HfAy-hiehojen, mutta laidunkauden päättyessä LiAy-eläimet olivat edelleen kevyempiä kuin HfAy-eläimet. Ruokinta ei vaikuttanut hiehojen elopainon kehitykseen.

Emän rotu tai ruokinta ei vaikuttanut vasikoiden kehitykseen. Syntymästä vieroitukseen $\mathrm{Ab} \times \mathrm{Hf} A y-$ sonnivasikat kasvoivat keskimäärin $1101 \mathrm{~g} / \mathrm{pv}$ ja $\mathrm{Ab}$ $\times$ LiAy-sonnivasikat $1054 \mathrm{~g} / \mathrm{pv}$, lehmävasikat vastaavasti 1015 ja $921 \mathrm{~g} / \mathrm{pv}$. Ab $\times$ LiAy-vasikoiden hieman heikompaan kasvuun vaikutti ilmeisesti LiAy-emojen HfAy-emoja hieman myöhäisempi poikimisajankohta. Vasikoiden keskimääräinen vieroitusikä oli 151 vuorokautta.

Sisäkauden ruokinta ei vaikuttanut emojen maidontuotantoon eikä tiinehtymiseen laidunkaudella. HfAy-emojen maidontuotanto oli keskimäärin LiAyemojen maidontuotantoa parempi. Laidunkaudella kaikki HfAy-emot ja 87,1\% LiAy-emoista tiinehtyivät.

Tutkimuksen perusteella heinä- ja säilörehuvaltainen ruokinta soveltuu risteytyshiehojen sisäruokintakaudelle. Suositusten alle jäänyttä kuiva-aineen syöntiä voidaan lisätä lisäämällä dieettiin heinää tai olkea. Tämän kokeen perusteella Aberdeen Angusta voidaan suositella risteytyshiehojen ensimmäiseen poikimiseen. 